\title{
Pengenalan Konsep Matematika pada Anak Usia Dini melalui Lagu
}

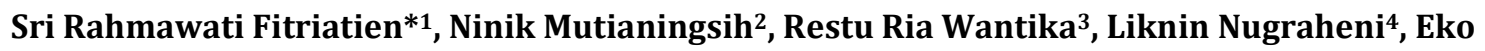 \\ Sugandi ${ }^{5}$ \\ 1,2,3,4,5 Program Studi Pendidikan Matematika, Fakultas Keguruan dan Ilmu Pendidikan, Universitas PGRI \\ Adi Buana Surabaya \\ *e-mail: rahmawatien.srf@unipasby.ac.id¹, ninikmutia@unipasby.ac.id² ${ }^{2}$ restu@unipasby.ac.id ${ }^{3}$, \\ $\underline{\text { liknin@unipasby.ac.id }}^{4}$, s_gandi@unipasby.ac.id ${ }^{5}$
}

\begin{abstract}
The comprehension concept of number and geometric shape in early childhood is needed to develop children's interest to mathematic. Introducing the concept of number and geometry in early childhood is first step of learning mathematic in order to the learning process is more fun and children do not scared of mathematic. To motivate children's favorite level to mathematic, the devotion team of Study Program Mathematic Education at PGRI Adi Buana Surabaya do assistance activities to PAUD teacher in Gondang, Mojokerto with the aim to introducing mathematical concept in early childhood through song. Kecamatan Gondang Kabupaten Mojokerto was selected based on an analysis of environmental conditions obtained when the team made observations related to mathematics learning at PAUD level. While the song was chosen by devotion team as an alternative learning media because it was based on the result discussion with PAUD teacher community when the team survey state that through song it was able to give pleasure to children. This activity consist of 10 devotion teams that consist of 5 lecturers and 5 students with 28 PAUD teacher from 64 in Gondong, Mojokerto based on the evaluation of PAUD supervisors. The result achieved from this activity are able to contribute to PAUD teacher in creating poetry and song lyric related to mathematical concept. The program sustainability plan is to register the copyright of the song by PAUD teacher as intelectual property.
\end{abstract}

Keywords: number, geometric shape, song, early childhood

\begin{abstract}
Abstrak
Pemahaman konsep bilangan dan bentuk geometri pada anak usia dini sangat diperlukan guna membangun minat anak terhadap matematika. Memperkenalkan konsep bilangan dan bangun geometri pada anak usia dini merupakan langkah awal dari pembelajaran matematika agar proses belajar lebih menyenangkan dan anak tidak merasa takut dengan matematika. Untuk memotivasi tingkat kesukaan anak terhadap matematika, tim pengabdian Program Studi Pendidikan Matematika Universitas PGRI Adi Buana Surabaya melakukan kegiatan pendampingan terhadap Bunda PAUD se-Kecamatan Gondang Kabupaten Mojokerto dengan tujuan pengenalan konsep matematika pada anak usia dini melalui lagu. Wilayah Kecamatan Gondang Kabupaten Mojokerto dipilih berdasarkan analisis kondisi lingkungan yang diperoleh saat tim melakukan observasi terkait pembelajaran matematika di tingkat PAUD. Sedangkan pemilihan lagu sebagai alternatif media pembelajaran karena berdasarkan hasil diskusi dengan paguyuban Bunda PAUD ketika tim melakukan survey menyatakan bahwa melalui lagu mampu memberikan rasa senang kepada anak.. Kegiatan ini beranggotakan 10 tim pengabdian yang terdiri dari 5 orang dosen dan 5 orang mahasiswa dengan peserta 28 orang dari 64 Bunda PAUD se-Kecamatan Gondang Kabupaten Mojokerto berdasarkan penilaian pengawas PAUD. Hasil yang dicapai dari kegiatan pengabdian ini adalah mampu memberikan kontribusi kepada Bunda PAUD dalam mencipta syair dan lirik lagu yang berkaitang dengan konsep matematika. rencana keberlanjutan program adalah mendaftarkan Hak Cipta lagu karya Bunda PAUD sebagabai kekayaan intelektual.
\end{abstract}

Kata kunci: bilangan, bangun geometri, lagu, anak usia dini

\section{PENDAHULUAN}

Dewasa ini banyak tersebar lagu secara luas di masyarakat yang kebanyakan konten dari syair maupun lirik lagu tidak sesuai dengan karakter anak usia dini, terlebih lagu yang tersebar di msyarakat tidak membantu proses belajar anak. Banyaknya lagu yang tidak sesuai untuk proses perkembangan dan kemampuan anak dalam belajar, menuntut Bunda PAUD sebagai guru dapat menciptakan lagu yang sesuai dengan karakteristik anak usia dini. Bunda PAUD dituntut untuk mampu menciptakatan kreativitas dalam mencipta lagu baik untuk menemukan nada, lirik, 
maupun pengetahuan serta pengalaman guna mencipta lagu anak yang berkaitan dengan pembelajaran di kelompok belajar. Selain itu, kegiatan ini dilatarbelakangi oleh keprihatinan terhadap perkembangan lagu anak di tingkat usia dini yang berkembang tidak seiring dengan perkembangan lingkungan sosial anak.

Permasalahan yang dihadapi oleh Bunda PAUD dalam mengajarkan matematika untuk konsep bilangan dan bangun geometri pada anak usia dini banyak adanya penggubahan lirik dari lagu yang telah ada. Hal ini merupakan tantangan bagi Bunda PAUD untuk menciptakan kreativitas secara berkelanjutan untuk mencipta lagu anak sesuai dengan tema pembelajaran. Menurut Prahesti dkk (Prahesti, Taulany, \& Dewi, 2019) menyatakan bahwa kreativitas merupakan kunci utama yang harus dimiliki oleh guru untuk anak usia dini guna menciptakan kegiatan pembelajaran yang menyenangkan.

Anak usia dini memiliki kapasitas memori yang cukup kuat, akan tetapi tidak semuanya mampu diingat dengan baik oleh anak (Fakhriyani, 2016), (Sembiring, Sriwahyuni, \& Marta Efastri, 2017). Lagu merupakan salah satu hal yang mampu diingat dengan mudah oleh anak usia dini karena dianggap menyenangkan (Kusumawati, 2015). Hal ini diperkuat pula melalui hasil diskusi tim pengabdian Program Studi Pendidikan Matematika Universitas PGRI Adi Buana Surabaya dengan kelompok paguyuban Bunda PAUD Kecamatan Gondang Kabupaten Mojokerto saat melakukan survey kegiatan pengabdian. Bunda PAUD menyampaikan informasi bahwa lagu digunakan sebagai salah satu media pembelajaran kepada anak di kelompok bermain saat anak mengikuti kegiatan pembelajaran. Akan tetapi lagu yang digunakan belum menyentuh secara menyeluruh untuk pengenalan dan pemahaman konsep bidang matematika.

Perwakilan Bunda PAUD di Kecamatan Gondang Kabupaten Mojokerto memaparkan pula bahwa banyak anak-anak yang terhipnotis dengan lagu-lagu yang beredar luas di masyarakat. Terlebih dengan adanya media sosial dimana dapat diakses secara luas oleh anak. Hal ini membuat sebagain besar Bunda PAUD yang juga selaku orang tua merasa khawatir atas perkembangan kemampuan berfikir dan kecerdasan anak di tahun-tahun mendatang.

Pada fase tertentu, anak usia dini mampu merekam dan menirukan gaya orang dewasa yang peruntukannya tidak ditujukan untuk anak (Diananda, 2018), (Vinayastri, 2015). Anak mampu mengulangi dalam kehidupan sehari-hari sekalipun tidak secara langsung implementasinya pada saat itu, akan tetapi kemampuan memori anak dapat menyimpan dalam jangka waktu yang lama (Bauer, 2019), (Nuryati, 2018), dan (Waldfogel, 2017). Anak usia dini masih memiliki dunia khayal sendiri di aspek kehidupan baik di dalam keluarga (Saleh, 2019) maupun dalam kegiatan bersosialisasi (Hamid, 2019) yang dalam hal ini digambarkan pada kegiatan belajar bersama dengan kelompok anak seusia pada kelompok belajar dengan gaya komunikasi yang unik (Suyanto, 2015).

Lagu memiliki pesan moral tersendiri yan digunakan untuk mendidik anak baik dari sikap, emosi, empati, dan daya kreativitas anak dalam menikmati proses pembelajaran yang dilalui (Nurjannah, 2017). Terlebih untuk pembelajaran yang diikuti oleh anak usia dini dengan belajar konsep matematika baik untuk bilangan (Holmes \& Hallam, 2017), (Hornburg, Schmitt, \& Purpura, 2018) maupun konsep bangun geometri (Ranelli, Smith, \& Straker, 2015), (Tezer, Cumhur, \& Hürsen, 2016).

Berdasarkan observasi dan wawancara awal dengan pemerintah Kecamatan Gondang Kabupaten Mojokerto dan perwakilan Bunda PAUD, tim pengabdian merasa perlu untuk melakukan kegiatan program pengabdian kepada masyarakat dengan sasaran Bunda PAUD seKecamatan Gondang Kabupaten Mojokerto. Perwakilan dari kelompok Bunda PAUD juga memberikan informasi bahwa hampir tidak ada lagu baru yang diciptakan oleh kelompok Bunda PAUD di wilayah Kecamatan Gondang Kabupaten Mojokerto, rata-rata masih menggunakan sadauran atau modifikasi lagu anak yang sudah ada baik yang diciptakan oleh Bunda PAUD sendiri atau dari pihak lain. Kondisi ini bisa saja terjadi dikarenakan kurangnya pengetahuan terkait konsep bidang tertentu (misalnya, matematika) yang dapat dijadikan sebagai materi pembelajaran pada anak usia dini dalam bentuk penyajian lagu anak bertemakan matematika, 
kurangnya Bunda PAUD dalam kegiatan-kegiatan yang mengasah kemampuan dan keterampilan dalam cipta lagu anak baik yang diselenggarakan pihak pemerintah ataupun lainnya, dan kurangnya sarana prasarana dalam keikutsertaannya Bunda PAUD dalam kegiatan-kegiatan pelatihan atau pendampingan. Edukasi ini diharapkan mampu memberikan pendampingan dalam memperkenalkan konsep dan pemahaman matematika terkait bilangan dan bangun geometri melalui lagu. Lagu digunakan sebagai alternatif media pembelajaran kepada anak usia dini sehingga dapat meminimalisir dampak negatif dari lagu yang tidak mendukung proses perkembangan berfikir anak dan mengurangi dampak negatif dari lagu anak yang tidak sesuai dengan perkembangan anak usia dini.

\section{METODE}

Kegiatan pengabdian kepada masyarakat ini dilaksanakan tanggal 4 Februari sampai dengan 6 Maret 2020 di Balai Kecamatan Gondang Kabupaten Mojokerto dengan sasaran kelompok Bunda PAUD se-Kecamatan Gondang Kabupaten Mojokerto dipilih berdasarkan informasi perangkat pemerintah kecamatan bahwa Bunda PAUD di wilayah ini masih jarang diikutsertakan dalam kegiatan pelatihan atau pendampingan guna peningkatan pembelajaran di tingkat PAUD. Jarang sekali ada kegiatan yang melibatkan Bunda PAUD dalam kegiatan yang memperkenalkan konsep matematika untuk anak usia dini.

Tim pengabdian kepada masyarakat terdiri dari 10 orang yang meliputi 5 orang dosen dan 5 orang mahasiswa Program Studi Pendidikan Matematika Universitas PGRI Adi Buana Surabaya. Peserta kegiatan ini adalah Bunda PAUD se-Kecamatan Gondang Kabupaten Mojokerto yang berjumlah 28 orang dari 64 Bunda PAUD se-Kecamatan Gondang Kabupaten Mojokerto berdasarkan penilaian pengawas PAUD.

Secara umum, pelaksanaan kegiatan "Pengenalan Konsep Matematika pada Anak Usia Dini melalui Lagu" ini menggunakan metode ceramah, diskusi, dan praktik supaya Bunda PAUD dapat menikmati setiap materi yang diberikan oleh narasumber kegiatan sesuai dengan jadwal yang sudah ditetapkan.

a. Ceramah

Metode ceramah digunakan untuk memberikan pemaparan dan penjelasan materi terkait pengertian konsep matematika pada anak usia dini, hubungan konsep matematika dengan kemampuan kecerdasan logis matematika pada anak usia dini, dan lagu sebagai media guna melatih kecerdasan logis matematika pada anak usia dini.

b. Diskusi

Metode diskusi digunakan untuk diskusi peserta dan pemateri, tanya jawab materi yang telah disampaikan oleh pemateri, dan saling memberikan tanggapan serta masukan terhadap permasalahan yang terjadi di dunia pendidikan anak usia dini terkait penanaman konsep matematika.

c. Praktik

Metode praktik digunakan untuk mempresentasikan atau menampilkan secara kongkret contoh atau karya lagu yang sudah dibuat sebagai media pembelajaran Bunda PAUD seKecamatan Gondang Kabupaten Mojokerto dalam memperkenalkan konsep matematika pada anak usia dini. Tim pemateri mempraktekkan secara langsung memperkenalkan konsep dan lambang bilangan, serta berbagai bentuk geometri. Pada tahapan ini, Bunda PAUD melakukan elaborasi guna menumbuhkan kreatifitas dalam mencipta lagu dan dapat digunakan pada saat di kelas kelompok belajar secara langsung. 

berikut.

Tahapan proses yang dilakukan oleh tim pengabdian dalam kegiatan ini adalah sebagai

a. Tahap Persiapan dan Pembekalan

Mekanisme persiapan dan pembekalan pada kegiatan "Pengenalan Konsep Matematika pada Anak Usia Dini melalui Lagu" ini meliputi tahapan-tahapan sebagai berikut: (1) menentukan jumlah mahasiswa yang terlibat dalam kegiatan pengabdian dan sasaran Bunda PAUD yang terlibat kegiatan, (2) melakukan koordinasi dan konsultasi dengan pihak Kecamatan Gondang Kabupaten Mojokerto dan Bunda PAUD, (3) melakukan pembekalan (coaching) kepada mahasiswa, dan (4) mempersiapkan sarana dan prasarana yang menunjang kegiatan pengabdian.

Materi yang digunakan dipersiapkan terlebih dahulu pada tahapan ini dan tim dosen memberikan pembekalan kepada mahasiswa yang meliputi teknis pembagian tugas, membuat panduan, serta perancangan model kegiatan pengabdian kepada masyarakat.

b. Tahap Pelaksanaan Kegiatan

Pelaksanaan kegiatan dilakukan dengan (1) mempersiapkan kegiatan yang dilakukan oleh tim pengabdian, (2) tim pengabdian berangkat ke tempat lokasi pengabdian yaitu Balai Kecamatan Gondang Kabupaten Mojokerto, (3) ketua tim pengabdian memberikan sambutan yang selanjutnya kegiatan pengabdian dibuka oleh Tim Kecamatan Gondang Kabupaten Mojokerto, (4) pengarahan lapangan oleh tim pengabdian, dan (5) melaksanakan kegiatan pengabdian sesuai dengan materi yang sudah dijadwalkan melalui metode ceramah, diskusi, dan praktik dalam pengenalan konsep matematika pada anak usia dini melalui lagu.

c. Tahap Pasca Kegiatan

Pasca pelaksanaan kegiatan pengabdian, tim pengabdian melakukan monitoring dan evaluasi dalam bentuk komunikasi dalam jaringan baik melalui komunikasi menggunakan whatsapp dan email kepada Bunda PAUD dalam mencipta karya lagu yang mencerminkan konsep dan lambang bilangan, serta berbagai bentuk geometri. Pemilihan pelaksanaan monitoring dan evaluasi oleh tim pengabdian dalam bentuk komunikasi dalam jaringan ini dikarenakan adanya wabah Covid-19 yang tidak memungkinkan untuk mengadakan monitoring dan evaluasi dengan cara tatap muka dan berkumpul.

Secara skematis pelaksanaan kegiatan pengabdian kepada masyarakat ini digambarkan pada Gambar 1. 


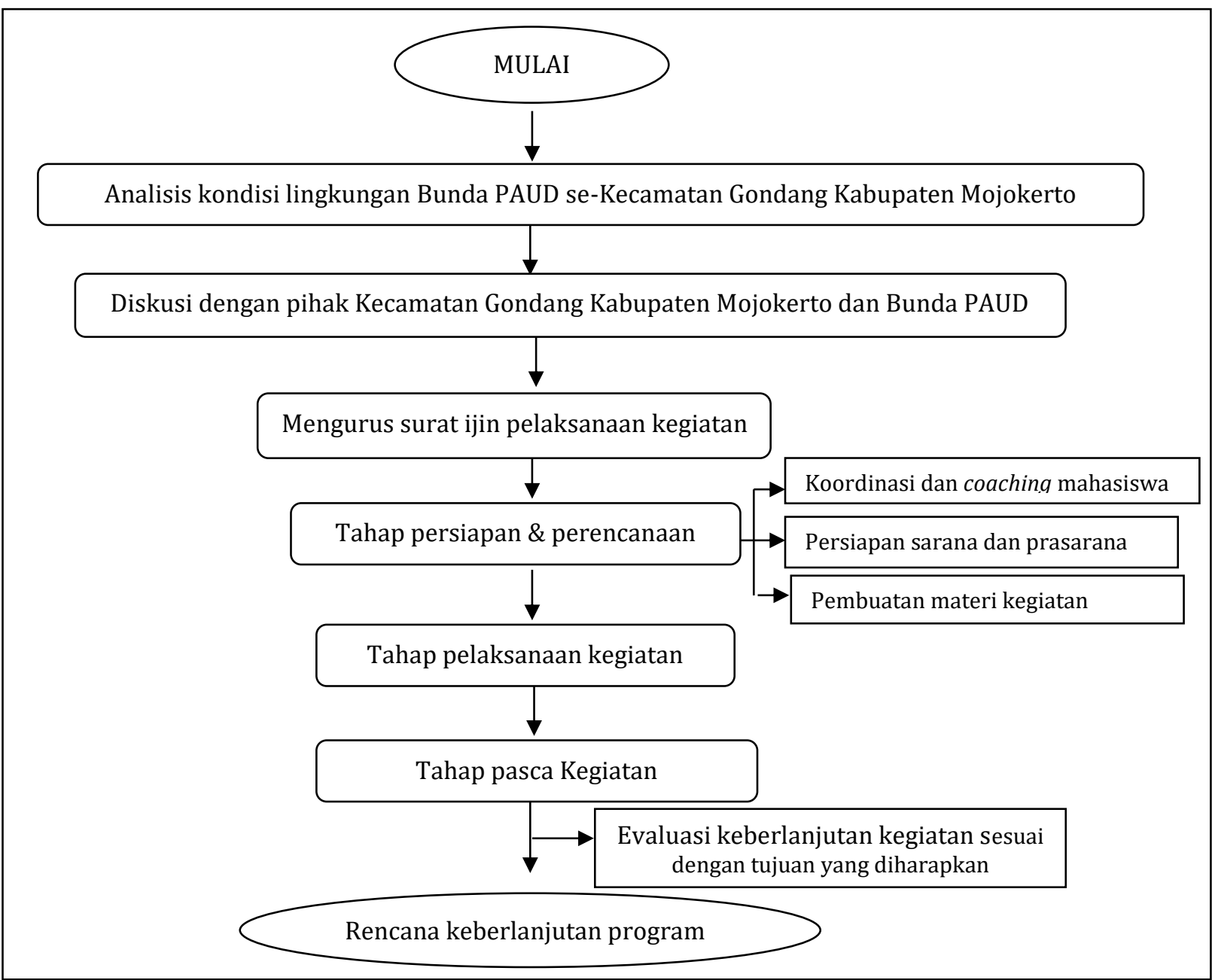

Gambar 1. Skema pelaksanaan kegiatan pengabdian kepada masyarakat

\section{HASIL DAN PEMBAHASAN}

Kegiatan yang dilaksanakan oleh tim pengabdian Program Studi Pendidikan Matematika Universitas PGRI Adi Buana Surabaya ini dilaksanakan sesuai dengan jadwal kegiatan yang ditampilkan pada Tabel 1.

Tabel 1. Jadwal dan materi kegiatan pengabdian kepada masyarakat

\begin{tabular}{|c|c|c|c|}
\hline Hari/Tanggal & Waktu & Materi Kegiatan & Narasumber Kegiatan \\
\hline $\begin{array}{c}\text { Selasa/4 Februari } \\
2020\end{array}$ & $08.30-11.30$ & $\begin{array}{l}\text { Konsep Matematika } \\
\text { pada Anak Usia Dini }\end{array}$ & $\begin{array}{c}\text { Sri Rahmawati } \\
\text { Fitriatien, S.Pd., M.Si. }\end{array}$ \\
\hline $\begin{array}{c}\text { Kamis/13 Februari } \\
2020\end{array}$ & $13.00-16.30$ & $\begin{array}{c}\text { Tahapan Penguasaan } \\
\text { Berhitung di } \\
\text { Matematika }\end{array}$ & $\begin{array}{l}\text { Ninik Mutianingsih, } \\
\text { S.Pd., M.Si. }\end{array}$ \\
\hline $\begin{array}{c}\text { Kamis/20 Februari } \\
2020\end{array}$ & $13.00-16.30$ & $\begin{array}{l}\text { Kreavitas Bunda } \\
\text { PAUD dalam Cipta } \\
\text { Syair Lagu }\end{array}$ & $\begin{array}{l}\text { Restu Ria Wantika, } \\
\text { S.Pd., M.Si. }\end{array}$ \\
\hline $\begin{array}{c}\text { Selasa/26 Februari } \\
2020\end{array}$ & $08.30-11.30$ & $\begin{array}{l}\text { Cipta Syair Lagu } \\
\text { Anak (1) }\end{array}$ & $\begin{array}{c}\text { Dr. Liknin Nugraheni, } \\
\text { M.Pd. }\end{array}$ \\
\hline Jumat/6 Maret 2020 & $13.00-16.00$ & $\begin{array}{l}\text { Cipta Syair Lagu } \\
\text { Anak (2) }\end{array}$ & $\begin{array}{c}\text { Eko Sugandi, S.Pd., } \\
\text { M.Pd. }\end{array}$ \\
\hline
\end{tabular}


Peserta kegiatan pengabdian sejumlah 28 orang Bunda PAUD yang merupakan perwakilan dari setiap kelompok belajar yang bertugas di wilayah Kecamatan Gondang Kabupaten Mojokerto. Selama kegiatan pengabdian berlangsung, terlihat antusiasme Bunda PAUD dalam mengajukan pertanyaan dan bahan diskusi kepada narasumber di setiap sesi kegiatan pengabdian berlangsung. Tidak jarang ketika peserta mengajukan pertanyaan atau mengajukan kasus yang dihadapi selama ini di lapangan memperoleh tanggapan dari peserta yang lain dan menanggapi penjelasan dari narasumber kegiatan baik selama pemaparan materi ataupun setelah materi diberikan. Setelah peserta mengikuti tiga rangkaian kegiatan pengabdian yang terlaksana pada tanggal 4 Februari 2020, 13 Februari 2020, dan 20 Februari 2020, peserta kegiatan pengabdian lebih banyak melakukan praktik secara berkelompok guna menciptakan syair lagu untuk anak usia dini yang berkaitan dengan pengenalan dan penanaman konsep matematika untuk anak usia dini.

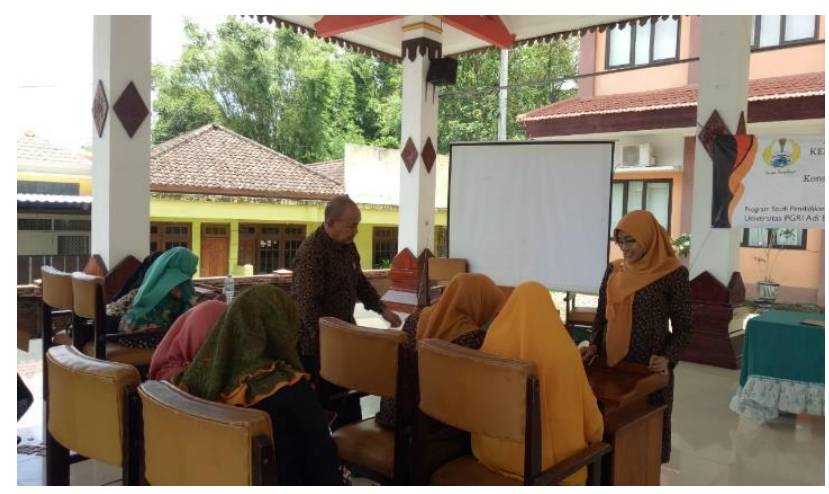

(a)

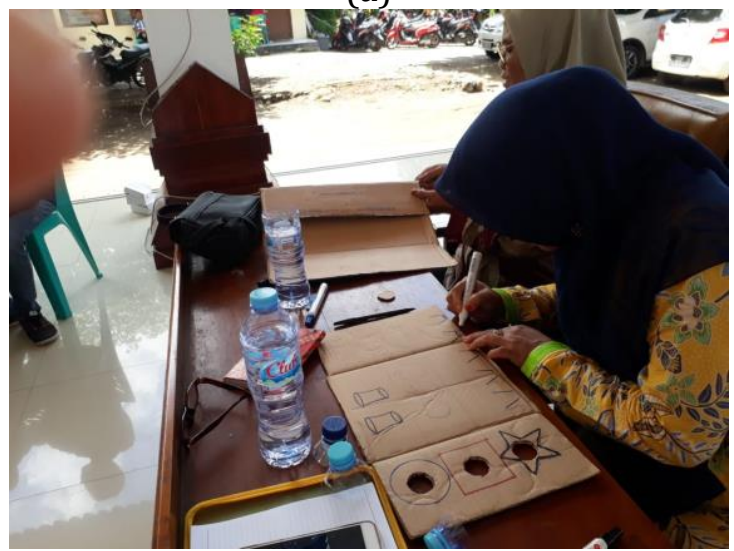

(c)

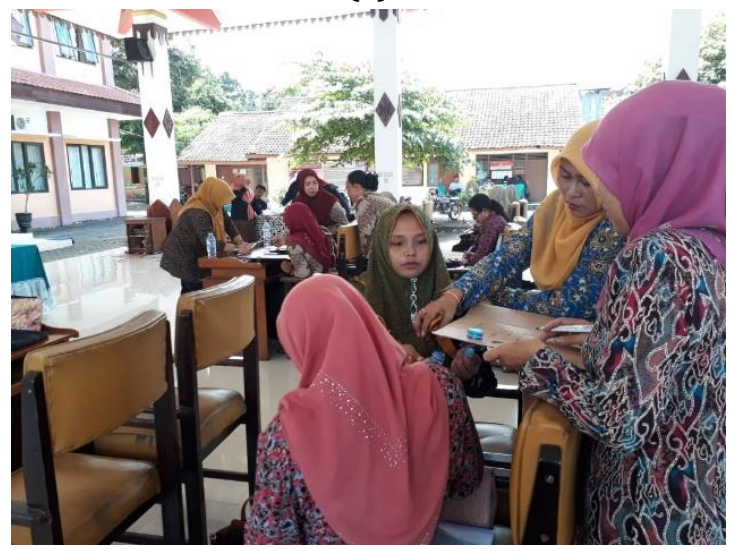

(e)

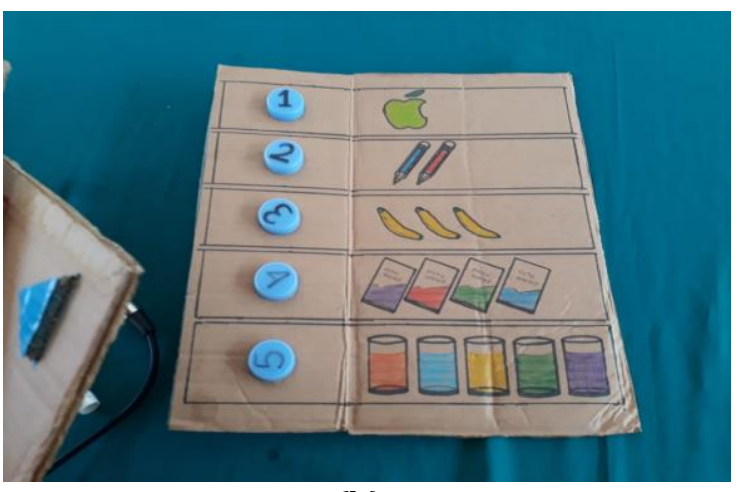

(b)

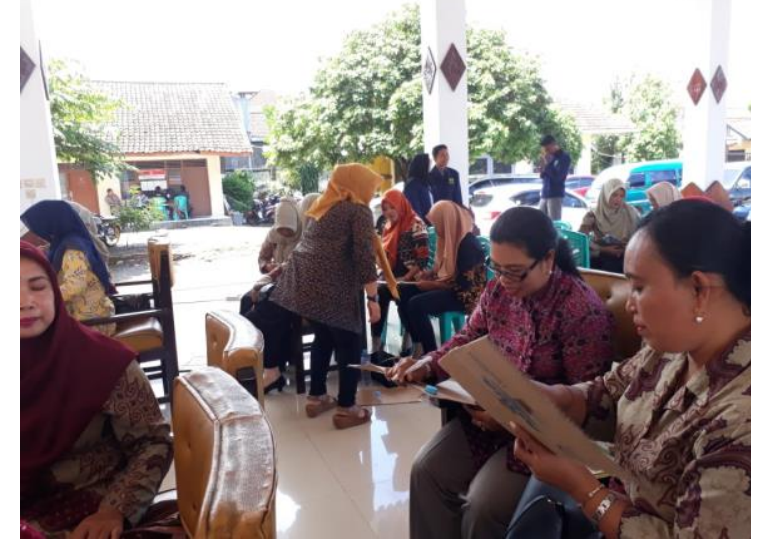

(d)

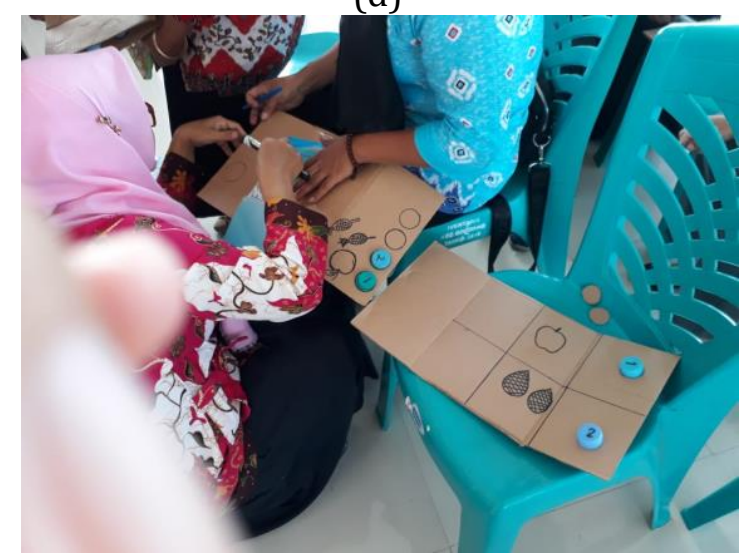

(f) 


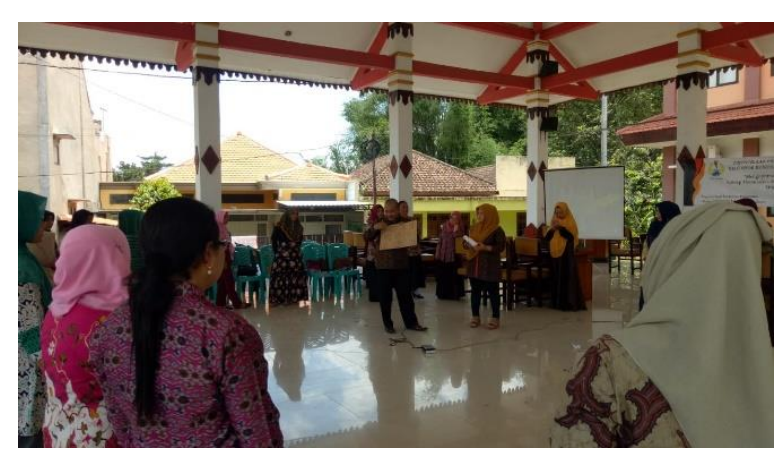

(g)

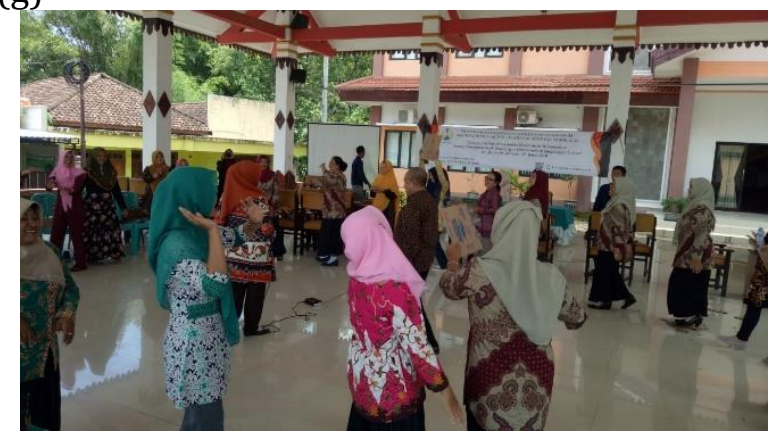

(i)

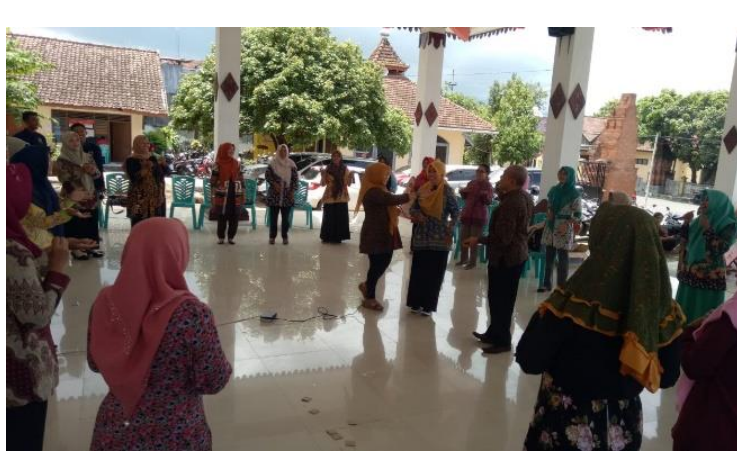

(h)

Gambar 2. Situasi pelaksanaan kegiatan

Pada sesi kegiatan pengabdian dengan materi cipta syair lagu anak, narasumber kegiatan memberikan contoh lagu anak yang sederhana dengan syair dan lirik lagu berkaitan dengan konsep matematika. Peserta kegiatan pengabdian yang telah dibagi menjadi beberapa kelompok memberikan kontribusi syair lagu pada sesi kegiatan ini pula. Setiap kelompok melakukan praktik langsung menyanyikan lagu untuk anak usia dini dengan syair dan lirik yang berkaitan dengan pengenalan dan konsep matematika.

Bentuk cipta syair lagu anak untuk usia dini ini dibatasi pada pengenalan, konsep, dan lambang bilangan, serta berbagai bentuk geometri. Salah satu karya syair lagu anak karya kelompok Bunda PAUD yang memperkenalkan konsep matematika pada anak usia dini disajikan dengan lirik.

Pada kegiatan praktik cipta syair lagu anak ini Bunda PAUD memaparkan bahwa istilah menghitung di udara adalah mengangkat jari ke atas sesuai dengan bilangan yang disebut. Kegiatan pengabdian dengan menggunakan lagu sebagai alternatif media pembelajaran pengenalan konsep matematika untuk anak usia dini yang memberikan stimulus kepada Bunda PAUD guna mencari ide dan kreativitas dalam membuat syair lagu yang akan digunakan di kelompok belajar masing-masing untuk mengajarkan matematika pada anak usia dini.

Temuan lain pada kegiatan pengabdian ini bahwa selama ini diajarkan oleh Bunda PAUD masih menggunakan syair lagu anak yang secara umum sudah biasa digunakan dan diperdengarkan baik oleh orangtua maupun oleh Bunda PAUD sendiri di kelompok belajar masing-masing. Hal ini terjadi di wilayah Kecamatan Gondang Kabupaten Mojokerto dikarenakan masih kurangnya perhatian dari pemerintah daerah memberikan pelatihan atau kegiatan yang melibatkan Bunda PAUD se-Kecamatan Gondang Kabupaten Mojokerto. Keikutsertaan Bunda PAUD pada kegiatan semacam ini biasanya hanya perwakilan 1 atau 2 orang dari setiap kelompok belajar di Kecamatan Gondang Kabupaten Mojokerto. Oleh sebab itu, antusiasme dari jajaran pemerintahan Kecamatan Gondang Kabupaten Mojokerto menyambut baik kegiatan pengabdian yang dilakukan oleh tim pengabdian Program Studi Pendidikan Matematika Universitas PGRI Adi Buana Surabaya, dan keikutsertaan Bunda PAUD selama kegiatan ini berlangsung sangat baik dan penuh semangat. 
Melalui kegiatan pengabdian ini pula, Bunda PAUD menghasilkan beberapa karya syair lagu dengan lirik pengenalan atau konsep matematika yang dapat membuat anak usia dini lebih senang belajar matematika sambal bernyanyi. Hal ini dapat dilakukan Bunda PAUD melalui lagu sebagai media pembelajaran yang dapat membuat siswa pada kelompok belajar mampu memahami konsep matematika yang abstrak menjadi lebih konkret sehingga kesukaan terhadap matematika tertanam sejak usia dini.

Rencana keberlanjutan program kegiatan selanjutnya sebagai rangkaian dari hasil pelaksanaan pengabdian ini, tim pengabdian akan mendaftarkan Hak Cipta syair lagu karya Bunda PAUD se-Kecamatan Gondang Kabupaten Mojokerto sebagai salah satu kekayaan intelektual.

\section{KESIMPULAN}

Kegiatan pengabdian kepada masyarakat di Balai Kecamatan Gondang Kabupaten Mojokerto untuk 28 orang Bunda PAUD se-Kecamatan Gondang ini dapat disimpulkan bahwa penggunaan lagu dapat digunakan untuk proses pembelajaran yang bermakna bagi anak usia dini. Lagu dapat membantu Bunda PAUD guna memperkenalkan konsep matematika berupa bilangan dan bangun geometri di kelompok belajarnya masing-masing. Selain itu, dari hasil kegiatan pengabdian ini pula mampu memberikan kontribusi nyata bagi kreativitas Bunda PAUD dalam menciptakan syair lagu dengan lirik yang berhubungan dengan matematika. Kegiatan pengabdian ini berlangsung dengan baik yang dapat dilihat dari antusiasme Bunda PAUD yang tinggi selama mengikuti rangkaian kegiatan pengabdian hingga selesai. Selain itu keterbukaan dari pihak pemerintah Kecamatan Gondang Kabupaten Mojokerto dalam membantu pelaksanaan kegiatan melalui penyediaan tempat pelaksanaan kegiatan pengabdian. Pelaksanaan kegiatan pengabdian yang dilakukan dalam periode relatif singkat ini masih memiliki kekurangan diantaranya adalah kurangnya sosialisasi dari tim pengabdian terkait pendaftaran Hak Cipta yang dapat dilakukan secara mandiri untuk karya Bunda PAUD yang telah dihasilkan selama ini. Oleh karena itu, kegiatan pengabdian kepada masyarakat selanjutnya dapat dilakukan dengan tema Hak Cipta untuk karya Bunda PAUD sebagai kekayaan intelektual. Setelah pelaksanaan kegiatan pengabdian ini, lagu yang diciptakan oleh Bunda PAUD terkait konsep matematika digunakan sebagai media alternatif memperkenalkan konsep matematika sehari-hari dan mudah dipahami oleh siswa. Informasi ini diperoleh oleh tim pengabdian setelah tim pengabdian melaksanakan kegiatan evaluasi dan tindak lanjut dari praktik membuat karya lagu bertema matematika dasar yang akan didaftarkan sebagai Hak Cipta syair lagu karya Bunda PAUD se-Kecamatan Gondang Kabupaten Mojokerto sebagai salah satu kekayaan intelektual.

\section{UCAPAN TERIMA KASIH}

Tim pengabdian kepada masyarakat Program Studi Pendidikan Matematika Universitas PGRI Adi Buana Surabaya mengucapkan terima kasih kepada Lembaga Penelitian dan Pengabdian kepada Masyarakat (LPPM) Universitas PGRI Adi Buana Surabaya yang telah memberi dukungan finansial terhadap pelaksanaan kegiatan pengabdian ini sehingga terlaksana dengan baik. Selanjutnya tim pengabdian mengucapkan terimakasih kepada seluruh petugas dan jajaran Kecamatan Gondang Kabupaten Mojokerto yang telah memberikan kesempatan kepada tim pengabdian yang memberikan ijin kegiatan dan menyediakan tempat untuk pelaksanaan, serta Bunda PAUD se-Kecamatan Gondang Kabupaten Mojokerto yang telah bersedia mengikuti kegiatan ini dengan baik hingga akhir pelaksanaan kegiatan. Semoga kegiatan ini dapat memberikan inspirasi kepada Bunda PAUD secara luas agar lebih kreatif dalam memperkenalkan matematika kepada anak usia dini sehingga menyukai matematika sejak dini. 


\section{DAFTAR PUSTAKA}

Bauer, K. J. (2019). The golden age. In America's Maritime Legacy: A History of the U.S. Merchant Marine and Shipbuilding Industry Since Colonial Times. https://doi.org/10.4324/9780429050770-2

Diananda, A. (2018). Urgensi Pendidikan Karakter dalam Pembentukan Konsep Diri Anak. Journal ISTIGHNA. https://doi.org/10.33853/istighna.v1i2.1

Fakhriyani, D. V. (2016). Pengembangan Kreativitas Anak Usia Dini. Wacana Didaktika. https://doi.org/10.31102/wacanadidaktika.4.2.193-200

Hamid, S. andriyani. (2019). Pendampingan Guru PAUD Ari-Ari Jepara dalam Meningkatkan Pembelajaran AUD Berbasis Budaya. Dinamisia: Jurnal Pengabdian Kepada Masyarakat. https://doi.org/10.31849/dinamisia.v3i1.2812

Holmes, S., \& Hallam, S. (2017). The impact of participation in music on learning mathematics. London Review of Education. https://doi.org/10.18546/LRE.15.3.07

Hornburg, C. B., Schmitt, S. A., \& Purpura, D. J. (2018). Relations between preschoolers' mathematical language understanding and specific numeracy skills. Journal of Experimental Child Psychology. https://doi.org/10.1016/j.jecp.2018.07.005

Kusumawati, H. (2015). Pendidikan Karakter Melalui Lagu Anak-Anak. Imaji. https://doi.org/10.21831/imaji.v11i2.3839

Nurjannah, N. (2017). Mengembangkan Kecerdasan Sosial Emosional Anak Usia Dini Melalui Keteladanan. Hisbah: Jurnal Bimbingan Konseling Dan Dakwah Islam. https://doi.org/10.14421/hisbah.2017.141-05

Nuryati. (2018). Pendidikan Anak Usia Dini. Jurnal Golden Age Universitas Hamzanwadi.

Prahesti, S. I., Taulany, H., \& Dewi, N. K. (2019). Gerak dan Lagu Neurokinestetik (GELATIK) untuk Menumbuhkan Kreativitas Seni Anak Usia Dini. Jurnal Obsesi : Jurnal Pendidikan Anak Usia Dini. https://doi.org/10.31004/obsesi.v4i1.289

Ranelli, S., Smith, A., \& Straker, L. (2015). The association of music experience, pattern of practice and performance anxiety with playing-related musculoskeletal problems (PRMP) in children learning instrumental music. International Journal of Music Education. https://doi.org/10.1177/0255761415597151

Saleh, A. (2019). Pemahaman Parenting Orang Tua Terhadap Keselamatan Lalu Lintas Untuk Anak Usia Dini Di TK Karya Bunda. Dinamisia: Jurnal Pengabdian Kepada Masyarakat. https://doi.org/10.31849/dinamisia.v3i2.2862

Sembiring, A. khudri, Sriwahyuni, S., \& Marta Efastri, S. (2017). Pendampingan Pembuatan Alat Permainan Edukatif dari Potensi Sumber Daya Alam. Dinamisia : Jurnal Pengabdian Kepada Masyarakat. https://doi.org/10.31849/dinamisia.v1i1.277

Suyanto, S. (2015). Pendidikan Karakter untuk Anak Usia Dini. Jurnal Pendidikan Anak. https://doi.org/10.21831/jpa.v1i1.2898

Tezer, M., Cumhur, M., \& Hürsen, E. (2016). The Spatial-Temporal reasoning states of children who play a musical instrument, regarding the mathematics lesson: Teachers' views. Eurasia Journal of Mathematics, Science and Technology Education. https://doi.org/10.12973/eurasia.2016.1262a

Vinayastri, A. (2015). Perkembangan Otak Anak Usia Dini. Jurnal Ilmiah WIDYA.

Waldfogel, J. (2017). How digitization has created a golden age of music, movies, books, and television. Journal of Economic Perspectives. https://doi.org/10.1257/jep.31.3.195 


\section{APENDIKS}

\section{Karya Cipta Lagu Kelompok 1}

lima bebek berenang

lewati danau yang jauh

ibunya berkata kwek kwek kwe

hanya empat ekor yang pulang

\#

empat bebek berenang

lewati bukit yang jauh

ibunya berkata kwek kwek kwe

hanya tiga ekor yang pulang

\#

tiga bebek berenang

lewati danau yang jauh

ibunya berkata kwek kwek kwe

hanya dua ekor yang pulang

\#

dua bebek berenang

lewati bukit yang jauh

ibunya berkata kwek kwek kwe

hanya satu ekor yang pulang

\#

satu bebek kecil berenang

lewati danau yang jauh

ibunya berkata kwek kwek kwe

dan semua bebek kecil pulang

(sambal bertepuk tangan) 


\section{Karya Cipta Lagu Kelompok 3}

one plus one

equals two

(menghitug di udara)*

satu tambah satu

sama dengan dua

\#

three minus two

equals one

(menghitug di udara)*

tiga kurangi dua

sama dengan satu

\#

we love

mathematics

kami suka

matematika

\#

two plus one

equals three

(menghitug di udara)*

dua tambah satu

sama dengan tiga

\#

four minus one

equals three

(menghitug di udara)*

empat kurangi satu

sama dengan tiga

$$
\begin{gathered}
\text { \# } \\
\text { we love } \\
\text { mathematics } \\
\text { kami suka } \\
\text { matematika }
\end{gathered}
$$

